\title{
Gigantism, taphonomy and palaeoecology of Basiloceras, a new oncocerid genus from the Middle Devonian of the Tafilalt (Morocco)
}

\author{
Alexander Pohle ${ }^{1}$ (D) Christian Klug ${ }^{1} \cdot$ Mischa Haas $^{2,3}$
}

Received: 13 September 2018 / Accepted: 16 January 2019/Published online: 31 January 2019

(C) Akademie der Naturwissenschaften Schweiz (SCNAT) 2019

\begin{abstract}
The genus Basiloceras gen. nov. containing the two species $B$. goliath sp. nov. and $B$. david sp. nov. is described. It belongs to the Acleistoceratidae within the Oncocerida. Both species are from the Middle Devonian of the Tafilalt (Morocco). The genus exhibits a large interspecific size range between the small Eifelian B. david sp. nov. and the Givetian B. goliath sp. nov., the largest Devonian oncocerid currently known, altogether only second to some fragmentary remains of Calchasiceras from the Carboniferous of Russia. Several other large species are mainly known from the late Emsian of Bohemia and the Eifelian of Germany. The holotype of B. goliath sp. nov. contains numerous epicoles, trace fossils and shell debris, which are discussed in the context of its taphonomy. Compared to other oncocerids, Basiloceras is characterised by a short body chamber, which might be related to buoyancy regulation. In contrast to some older publications, we do not regard breviconic oncocerids with contracted aperture as benthic or nektobenthic animals, but instead, we think that they dwelled in the water column.
\end{abstract}

Keywords Oncocerida $\cdot$ Cephalopoda $\cdot$ Gigantism $\cdot$ Epicoles $\cdot$ Taphonomy $\cdot$ Buoyancy

\section{Introduction}

Devonian non-ammonoid cephalopods from the Tafilalt of Morocco have long been treated only cursorily by researchers, despite the intense palaeontological research that has been carried out in the region for almost a century (for a literature review, see Becker et al. 2018; Klug and Pohle 2018 and references therein). After the pioneering work of Termier and Termier (1950), which included several descriptions of nautiloids amongst many other fossil groups, no significant contributions were made for about 50 years, until increased scientific effort resulted in several studies that included nautiloids in the past decade

Editorial Handling: D. Marty.

Alexander Pohle

alexander.pohle@pim.uzh.ch

1 Paläontologisches Institut und Museum, Universität Zürich, Karl-Schmid-Strasse 4, 8006 Zurich, Switzerland

2 Department of Earth Sciences, ETH Zürich, Sonneggstrasse 5, 8006 Zurich, Switzerland

3 Department of Surface Waters Research and Management, Eawag, Überlandstrasse 133, 8600 Dübendorf, Switzerland
(Kröger et al. 2005; Klug 2007; Klug et al. 2008; Kröger 2008; De Baets et al. 2010; Frey et al. 2014; De Baets and Munnecke 2018; Pohle and Klug 2018a, b). Nevertheless, many specimens await proper taxonomic descriptions as new material is still being recovered.

Here, we describe an unusually large oncocerid that was collected near Rich Tamirant between El Khraouia and Oum El Hadej in the southern Tafilalt (Morocco) from Givetian rocks (Fig. 1). We introduce the new genus Basiloceras, which includes the two species Basiloceras goliath sp. nov. from the Givetian and B. david sp. nov. from the Eifelian. We also discuss the systematic position of the genus and the taphonomy of the type species.

\section{Materials and methods}

We mostly use the terminology of the Treatise (Sweet 1964; Teichert 1964) with the addition of the term actinosiphonate lamellae in preference to actinosiphonate deposits to more clearly distinguish them from the endosiphuncular deposits of the Orthocerida or Actinocerida (see also Flower 1943, 1964; Crick and Teichert 1979; Mutvei 2011). Also note that height always refers to 


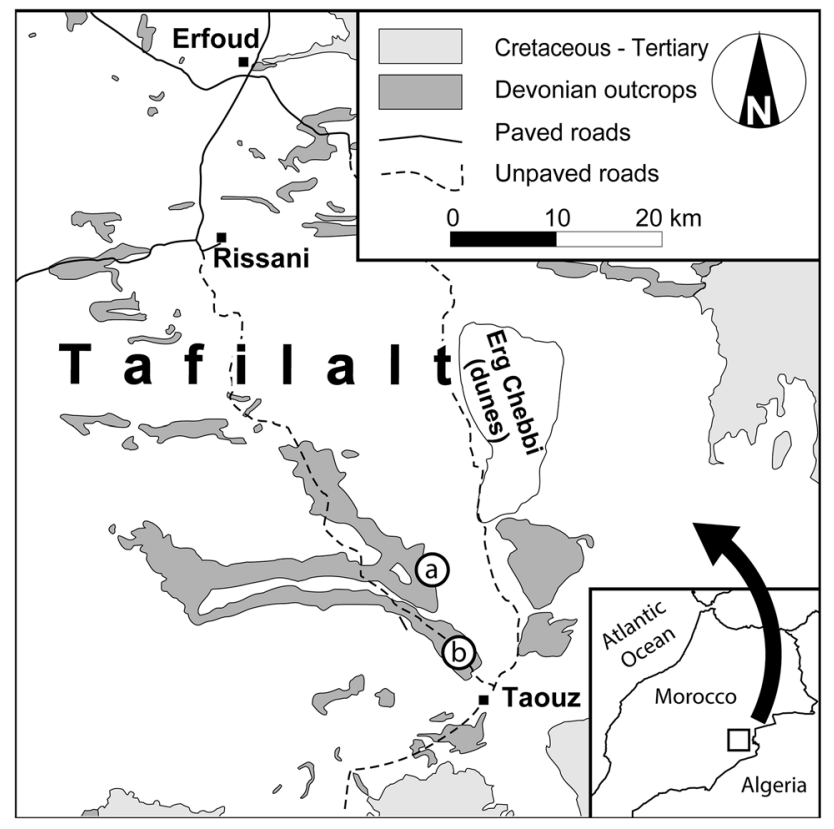

Fig. 1 Geological map of the southern Tafilalt. a Type locality of Basiloceras goliath, near Rich Tamirant. b Type locality of $B$. david, the Jebel Ouaoufilal

measurements in dorsoventral direction, width to measurements in lateral direction and length to measurements in longitudinal direction of the conch. Furthermore, a contracted body chamber has its smallest diameter at the peristome, while a constricted aperture has its smallest diameter behind the peristome. We orient the specimens on figures with the aperture downwards, in accordance with Stridsberg (1985, 1990a) and Pohle and Klug (2018b).

All specimens are housed at the Paläontologisches Institut und Museum of the Universität Zürich, Switzerland (PIMUZ).

\section{Previous reports of large Devonian oncocerids}

Large species, sometimes dubbed giants (gigantism), evolved independently and numerous times in several clades of cephalopods (Landois 1895; Teichert and Kummel 1960; Stevens 1988; Manger et al. 1999; Kubodera and Mori 2005; Iba et al. 2015; Klug et al. 2015; Rosa et al. 2017; Pohle and Klug 2018a). However, in some groups such as the Oncocerida, giants are much less common (although this depends on the definition of giants; see Klug et al. 2015). In general, oncocerids are small, i.e. specimens with cross section diameters above $100 \mathrm{~mm}$ are rare; such taxa are accordingly here considered to be large. The species described here as Basiloceras goliath $\mathrm{sp}$. nov. has a maximum conch width of at least $180 \mathrm{~mm}$ and is, therefore, a true giant among the Oncocerida. To our knowledge, there is only one report of a possibly larger oncocerid: several specimens of Calchasiceras ventricosum (M'Coy, 1844) from the Early Carboniferous of Russia were reported by Shimansky (1968) to reach diameters between 180 and $240 \mathrm{~mm}$.

Similar cases have been reported only occasionally from the Devonian. Most notably, Barrande (1865-1877) described and illustrated six very large species from the late Emsian of Bohemia: Phragmoceras devonicans Barrande, 1865, Cyrtoceras empiricum Barrande, 1877, C. palinurus Barrande, 1877, C. lumbosum Barrande, 1877, C. turnus Barrande, 1877 and C. imperans Barrande, 1877. Later, Foerste (1926) erected the genera Paracleistoceras, Blakeoceras, Conostichoceras, Poteriocerina and Turnoceras based on the former five of these species. All of these come from the late Emsian Třebotov limestone (there is some misunderstanding in the literature concerning the age of the Třebotov limestone; see Chlupáč et al. 1979; Chlupáč 1983; Manda and Turek 2011) and have a maximum diameter between 100 and $140 \mathrm{~mm}$. The largest of Barrande's species, "C." imperans, reached diameters of $160 \mathrm{~mm}$. However, as these remains are poorly preserved and the position of the siphuncle is unknown, the material of the latter species was not reinvestigated by later researchers. According to Dzik (1984), all the species mentioned above belong to the genus Paracleistoceras. Without having reinvestigated the original material, we tend to agree with Dzik's (1984) view, perhaps with the exception of the genus Blakeoceras, which differs from Paracleistoceras in its compressed cross section, stronger curvature and broader siphuncle.

Several other large species have been assigned to the genus Cyrtoceratites Goldfuss, 1830 (or many other, probably incorrect secondary spellings, such as Cyrtoceras, Cyrtocera, and Cyrthoceratites ), however, most of them are markedly cyrtoconic or even gyroconic, and thus clearly differ from the less strongly curved Bohemian species and the straight Basiloceras gen. nov. One specimen from the Middle Devonian of Canada described as Cyrthoceratites aff. C. lineatus D'Archiac and De Verneuil, 1852 by Collins (1969) has a maximum conch diameter of $150 \mathrm{~mm}$. More recently, another large " $\mathrm{Cyr}$ toceratites" from the Eifelian of El Gara (Tafilalt) was reported by Afhüppe et al. (2018) and Becker et al. (2018).

It is apparent that the late Emsian to Eifelian was a period where several large oncocerid species occurred that share an exogastric conch curvature and a siphuncle with continuous actinosiphonate lamellae. However, as most of these species require revision, their taxonomic affinities are unclear. Various authors have placed them in the Acleistoceratidae Flower, in Flower and Kummel 1950, Cyrtoceratidae Chapman, 1857, Jovellaniidae Foord, 1888 or 
Nothoceratidae Fischer, 1882 (Flower and Kummel 1950; Zhuravleva 1962, 1974; Sweet 1964; Dzik 1984). Curiously, no author placed all of them within the same family, despite the morphological similarities. Detailed studies of the siphuncular structures are needed to clarify whether gigantism occurred at the same time independently in several oncocerid lineages or whether these giants represent a monophyletic group. In contrast to the Bohemian and German giant oncocerids, the only known siphuncular segment of Basiloceras lacks actinosiphonate lamellae, which suggests that large size evolved independently at least twice in oncocerids during the Devonian. Possibly, the large size of these oncocerids evolved as a response to the rise of large arthrodires and chondrichthyans (Brett and Walker 2002; Klug et al. 2010, 2017; Dahl et al. 2011; Brazeau and Friedman 2015), which probably also preyed on cephalopods (Klug 2007).

\section{Taphonomy}

The holotype of Basiloceras goliath sp. nov. (PIMUZ 35928) shows some taphonomic peculiarities. After its death and the subsequent settling on the sediment surface, it came to rest on its dorsal side. This is corroborated by the sedimentary filling containing coarse bioclasts, by the better preservation of the dorsal side including peristome and phragmocone, and by the greater extent of phragmocone sediment filling. Remarkably, numerous fossils are associated with the cephalopod conch. Partially, the conch served as a benthic island (Seilacher 1982), as fossil trap and as cryptic habitat.

Encrustations of cephalopod shells by various organisms since the Ordovician have been reported in many publications (e.g., Watkins 1981; Baird et al. 1989; Davis et al. 1999; Klug and Korn 2001; Kröger et al. 2009; Landman et al. 2010; Rakociński 2011; Wyse Jackson and Key 2014; Hautmann et al. 2017). The surface of the holotype of $B$. goliath also shows remains of several epibionts and trace fossils, which allows us to make some inferences about its taphonomy (Fig. 2).

We recovered three articulate brachiopods from the inside of the dorsum of the incomplete phragmocone (Fig. 3). Although the preservation is poor, they clearly belong to different species, here provisionally assigned to cf. Schizophoria sp. (Fig. 3a, b), Gypidulidae indet. (Fig. 3c, d) and Orthida indet. (Fig. 3e) (personal communication Adam T. Halamski, July 2018). Finer taxonomic assignment is impossible, but there is some similarity to other Middle Devonian brachiopod associations from the eastern Anti-Atlas (compare, e.g., Halamski and Baliński 2013). These brachiopods were either settling on the conch, on the prefossilized specimen or washed into the broken phragmocone by currents (fossil trap; cf. Wani 2007).

In addition, several valves of other brachiopods are visible at the surface of the body chamber and phragmocone (Fig. 2c). They are subcircular, appear to have a slightly thickened shell at the margin, concentric growth lines, and appear to be preserved in calcite. Some of them may belong to inarticulate brachiopods, which have been shown to frequently encrust Ordovician orthoconic nautiloids (Gabbott 1999) and Jurassic ammonites (Seilacher 1982), but many inarticulates have chitinophosphatic shells, which is not the case here. It is not even clear whether these valves are truly brachiopods or bivalves. The encrusters are almost entirely restricted to the ventral side (taphonomically the upper side) and only two very questionable specimens occur on the dorsum. They are not restricted to the body chamber and sometimes cross septa. Their appearance and preservation is reminiscent of the Triassic bivalve Placunopsis, which also often inhabited the inside of cephalopod conchs (e.g., Hölder 1990; Todd and Hagdorn 1993; Klug and Lehmkuhl 2004; Klug et al. 2004; Pruss et al. 2007).

Additionally, the ventral side of the conch carries about 30-40 corroded microconchids (Fig. 2b), small spiral tubes that were formed by organisms related to tentaculites (Weedon 1991; Taylor and Vinn 2006; Vinn 2006; Zatoń and Olempska 2017). Similar to the subcircular valves, they are only found on the ventral side of the conch of $B$. goliath. The microconchids may belong to the genus Palaeoconchus Vinn, 2006, one of only four genera known from the Devonian (Zatoń and Krawczyński 2011; Zatoń and Olempska 2017). However, this identification is provisional due to the poor preservation and the still very incomplete knowledge of this group. Currently, microconchids from Morocco have not received any attention, and thus they have not been investigated in systematic studies, although they have been reported to frequently encrust the Eifelian or Givetian brachiopod Glyptogypa (Halamski and Baliński 2013). Notably, we found no evidence of encrustation by crinoids, bryozoans, tabulate or rugose corals, which are also very common epicoles on cephalopod conchs (e.g., Klug and Korn 2001; Rakociński 2011; Wyse Jackson and Key 2014; Kröger and Aubrechtová 2018).

It is not entirely clear, whether the epicoles settled on the inside of the shell or on the internal mould. The microconchids are poorly preserved but judging from their appearance both interpretations appear possible (personal communication Olev Vinn, September 2018). The phragmocone is broken in one place, revealing that the septa were dissolved except for the outermost ridges; thus, the sutures are visible, but the septa did not provide obstacles for living or dead organisms to enter part of the 

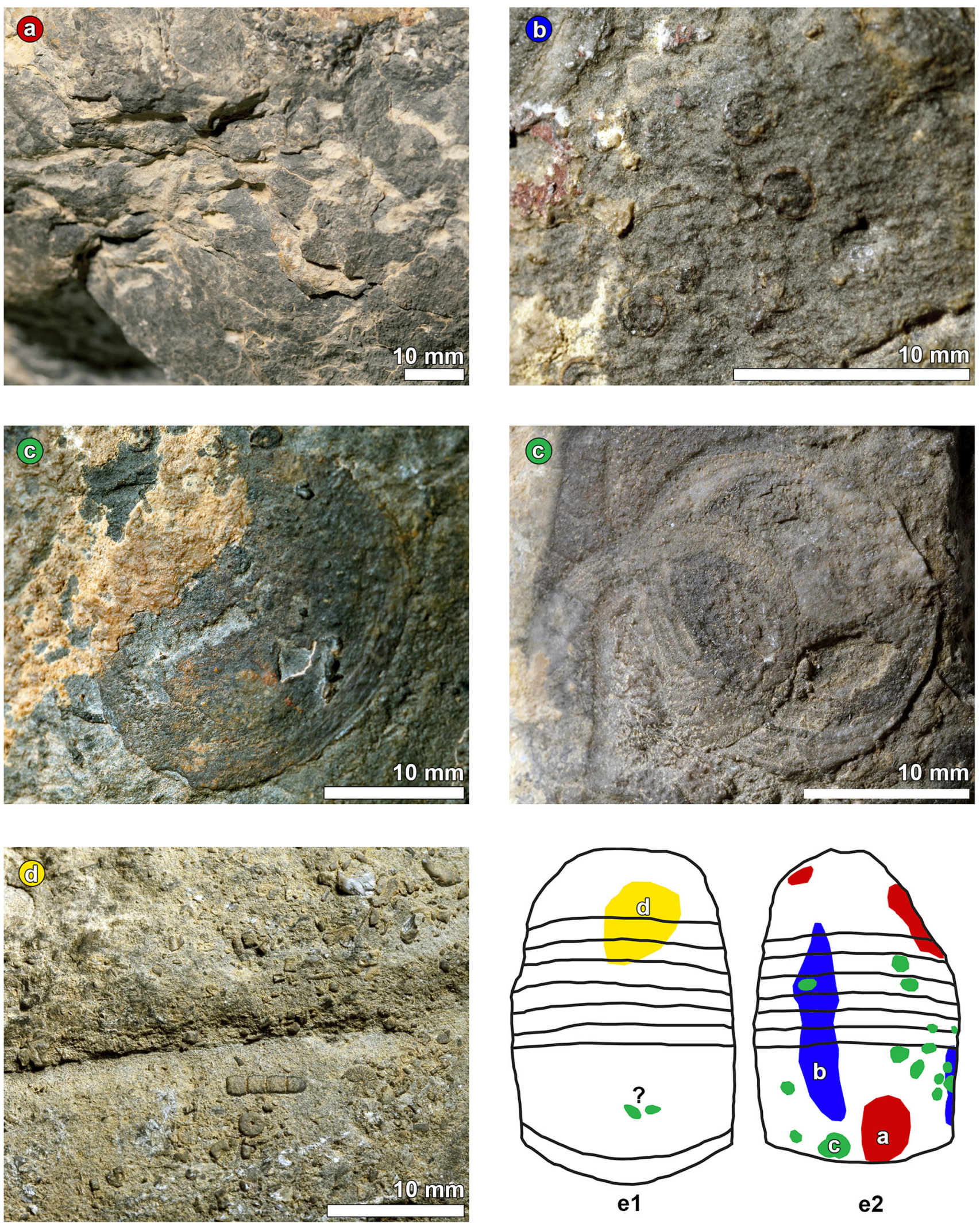
4Fig. 2 Post mortem epicoles of Basiloceras goliath sp. nov., holotype, PIMUZ 35927, Givetian, SE of Oum El Hadej. a (Red) trace fossils. b (Blue) microconchids, cf. Palaeoconchus sp. c (Green) encrusting bivalves or brachiopods. d (Yellow) shell debris, including shell fragments, small orthoconic cephalopods and crinoid columnals. e Outline of B. goliath sp. nov., holotype, PIMUZ 35927 in dorsal (e1) and ventral (e2) view. Colours indicate the distribution of trace fossils and epibionts on the conch

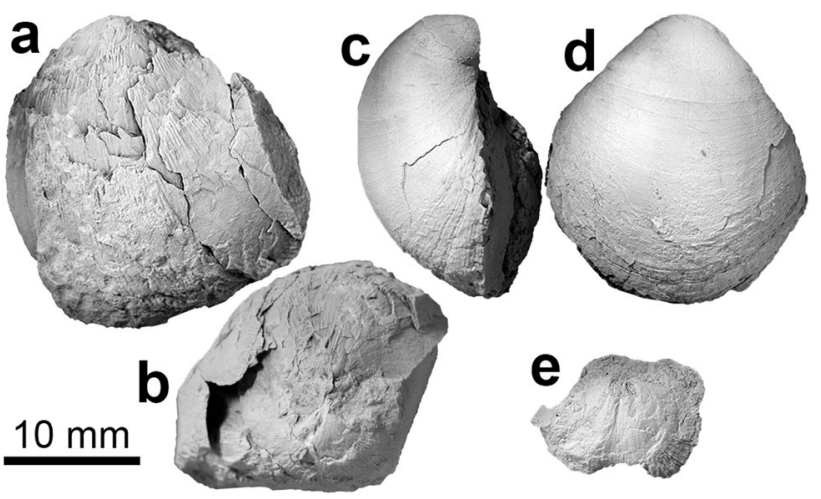

Fig. 3 Articulate brachiopods recovered from the phragmocone of Basiloceras goliath sp. nov., holotype, PIMUZ 35927, Givetian, SE of Oum El Hadej. All specimens were whitened with $\mathrm{NH}_{4} \mathrm{Cl}$. a, b Cf. Schizophoria sp., PIMUZ 35929, ventral and posterior view. c, d Gypidulidae indet., PIMUZ 35930, lateral and ventral view. e Orthida indet., PIMUZ 35931, ventral and lateral view

phragmocone. Alternatively, the septa were destroyed by another mechanism such as septal implosion during postmortem descent (e.g., Westermann 1973, 1985; Stridsberg 1990b). However, we consider this as unlikely as the rich benthos associated with the specimen indicates that the depositional environment was probably too shallow to cause septal implosion. In any case, the microconchids and brachiopods possibly used the inside of the shell as a cryptic habitat, where they were protected from predators. The wealth of epibenthos and trace fossils associated with this oncocerid indicates that the conch was deposited in a well-oxygenated, moderately shallow water environment.

The dorsal side exposes large numbers of small shell fragments and crinoid columnals (Fig. 2d), but entirely lacks brachiopods, bivalves, microconchids or trace fossils, which corroborates that the specimen was deposited with the dorsal side facing downwards. The shell was partially broken and filled with sediment including numerous conchs and shell fragments of other organisms.

\section{Ecological interpretation of Basiloceras}

The body chamber of Basiloceras is short compared to other oncocerids. There are claims that the body chamber of oncocerids is usually large in comparison with the phragmocone (e.g., Teichert 1967; Crick 1988; Frey 1989, 1995), however, a comparison with the literature suggests that both extremes exist and neither short nor long body chambers are significantly predominating (cf., e.g., Flower 1938; Sweet 1959, 1964; Zhuravleva 1972, 1974; Fyre 1987). According to the mathematical hydrostatic models of Westermann (1975), body chamber length is inversely correlated to the apical angle of the shell, and thus brevicones would tend to have short body chambers. The large variation in body chamber size among oncocerids requires some further considerations concerning the significance of this character. Presumably, a short open body chamber offers less protection than a long contracted one but possibly allows for more flexibility and mobility in the soft parts. Furthermore, changes in body chamber proportions must have been accompanied or even controlled by adaptations of the buoyancy apparatus. According to Teichert (1967), a major feature of cephalopod evolution is the response to buoyancy problems, amongst which the relative size of the body chamber is one solution. As the soft body of the animal and particularly the shell itself have a higher density than sea water (e.g., Denton and Gilpin-Brown 1966; Lemanis et al. 2014; Tajika et al. 2015), the relative size of the body chamber had an important impact on the buoyancy of the animal (e.g., Teichert 1967; Crick 1988). A smaller body chamber would thus require further buoyancy regulating mechanisms such as an increased amount of cameral liquid to prevent the animal to float up to the sea surface. In the case of a vertical, aperture down orientation as in breviconic oncocerids, an increased amount of cameral liquid would have the additional effect of reducing the distance between the centres of buoyancy and mass, which would possibly enhance manoeuvrability and facilitate horizontal as well as vertical movement. A detailed analysis of oncocerid body chamber size and its hydrostatic implications is beyond the scope of this study, but there is a great potential for future studies. In particular, volume models of the conchs would help testing the buoyancy and reconstructing the amount of chamber water needed for neutral buoyancy (cf. Tajika et al. 2015; Naglik et al. 2016).

Although the material of Basiloceras does not directly provide new information on the buoyancy of breviconic oncocerids, we want to make a few general statements on their mode of life. Flower (1957) remarked on the difficulties in interpreting the mode of life of oncocerids and concluded that many of them were likely bottom dwellers, although he also admitted that there were probably swimmers and floaters among them. Furnish and Glenister (1964) interpreted oncocerids as predominantly benthic because of the proportionally small phragmocone, but they mentioned the possibility that some groups were nektobenthic in view of the presence of a well-developed 
hyponomic sinus. Similar statements were made by Frey (1989) and Teichert (1967). However, in agreement with Westermann (1973), we reject this interpretation because (1) the shell would be too big for a benthic animal without obvious benefit; (2) according to Clarke et al. (1979), there are four different solutions in extant cephalopods to achieve neutral buoyancy, of which a gas-filled phragmocone is just one and hence, there is no reason to assume that some nautiloids did not evolve another way of reducing their weight if the phragmocone alone was insufficient (such a mechanism was even suggested in oncocerids, see Niko and Nishida 2003; although their hypothesis has not been tested yet)-also considering the wealth of other organisms that evolved buoyancy mechanisms in many other different ways (in any case, non-functionality would probably cause an evolutionary reduction or loss of the phragmocone); (3) if the phragmocone was only used to slightly reduce the weight of the shell to ease carrying the shell or rapid escape movements, there would be no explanation for the enormous variability and complexity of the oncocerid siphuncle (e.g., Kröger 2003; Mutvei 2011, 2013).

Furthermore, contradicting statements were made by the same authors that advocated a benthic or nektobenthic lifestyle in that the short phragmocone chambers, large body chambers and possibly also the siphuncular structures were used to regulate buoyancy (Teichert 1967; Crick 1988; Frey 1989); so why would a primarily benthic animal need such a sophisticated buoyancy apparatus? Modern day Nautilus is only able to make very slight and slow adjustments to its buoyancy (Ward 1986) and actinosiphonate lamellae have been interpreted as increasing the efficiency of the siphuncle (Crick and Teichert 1979; Kröger 2003; Mutvei 2011). All these arguments suggest that oncocerids were well capable of living in the water column, possibly as vertical migrants (e.g., Kröger 2003; Mutvei 2011, 2013). However, because of the significant changes in apical angle and apertural contraction during ontogeny, the mode of life of juvenile oncocerids might have been quite different from that of adult individuals (Manda 2008; Manda and Frýda 2010).

\section{Conclusions}

We describe the new oncocerid genus Basiloceras with two species, $B$. david and B. goliath. Particularly the latter species attained a large conch size. Its conch could possibly reach a length of almost $1 \mathrm{~m}$, but these dimensions are only rough estimates, as it strongly depends on the apical angle of the phragmocone, its changes during ontogeny, the shape and size of the apex and whether conch truncation occurred as in some Silurian brevicones (see Stridsberg 1985).

Because of its huge size, it is not surprising that the empty conch was used by microconchids and various attached lophotrochozoans (brachiopods and possibly bivalves) as attachment surface (benthic island). Some specimens might alternatively have reached the conch by currents, where the empty conch functioned as a fossil trap. Some of the post mortem epicoles probably inhabited the inside of the empty body chamber and phragmocone, after some of the septa were broken or dissolved.

Both species of Basiloceras have a rather short body chamber. We discuss possible functions for the peculiar proportions and shape. In our opinion, body chamber proportions were in these cases mostly controlled by the requirements to maintain neutral buoyancy of this supposed vertical migrant. These hypotheses should be tested using quantitative volume models of oncocerid conchs in the future.

\section{Systematic palaeontology}

Class Cephalopoda Cuvier, 1797

Order Oncocerida Flower in Flower and Kummel, 1950

Family Acleistoceratidae Flower in Flower and Kummel, 1950

Remarks. Basiloceras is placed within the Acleistoceratidae based on its depressed exogastric breviconic conch shape, broadly expanded siphuncle and the lack of actinosiphonate lamellae (cf. Flower and Kummel 1950; Sweet 1964). However, the family-level classification of breviconic oncocerids needs revision and, therefore, some doubt remains regarding the family assignment. Dzik (1984) regarded the family as synonymous with the Brevicoceratidae Flower, 1941 (but assigned Paracleistoceras to the Jovellaniidae Foord, 1888), while other authors regarded the Acleistoceratidae as valid (e.g., Holland 2007; Gnoli and Serventi 2009).

Genus Basiloceras gen. nov.

Type species. Basiloceras goliath sp. nov.

Etymology. Basileus $(\mathrm{Gr})=.\mathrm{king}$, referring to the large size of the type species and the groove near the peristome, reminiscent of a crown.

Species included. Basiloceras goliath sp. nov. and Basiloceras david sp. nov., both from the Middle Devonian of the Tafilalt.

Diagnosis. The conch is straight in the adult and subadult stage with a slightly depressed cross section. Towards the adult peristome, the cross section becomes subtriangular 
with a distinctively flattened dorsum and a rounded venter. The body chamber is shorter than high and wide. It is contracted mainly on the dorsum and the venter, while the lateral sides are only slightly converging towards the aperture. Its aperture has a width of $c .0 .8$ and a height of c. 0.6 in relation to the maximal conch diameter at the base of the body chamber. The siphuncle is eccentric, close to the ventral side of the conch. The septal necks are cyrtochoanitic and the siphuncular segments broadly expanded, lacking actinosiphonate lamellae.

Discussion. Basiloceras is similar to Paracleistoceras Foerste, 1926 and Acleistoceras Hyatt, 1884 in general conch shape. However, it differs from both genera in the rounded subtriangular cross section of the body chamber and the convex dorsal outline, which is straight in Paracleistoceras and Acleistoceras. Furthermore, the conch of Paracleistoceras is clearly cyrtoconic, while it is more or less straight in Basiloceras, at least in the adult stage. The siphuncle of Paracleistoceras is located very close to the ventral side and contains continuous actinosiphonate lamellae, while it is removed from the shell wall by the distance of the siphuncular diameter in Basiloceras and lacks actinosiphonate lamellae at least in its adult stage. Acleistoceras differs furthermore in its longer body chamber and generally more elongate shape. Finally, the hyponomic sinus is smaller in Acleistoceras. Calchasiceras Shimansky, 1957 is similar in its short body chamber, but differs in its almost central siphuncle and the more oval cross section.

Remarks. In both species of Basiloceras, the juvenile part of the phragmocone is unknown. Presumably, it was curved exogastrically, as in the related Acleistoceras.

Basiloceras goliath sp. nov.

Figures 2, 4f-i, 5

Etymology. After Goliath, the biblical figure, referring to the large adult size.

Holotype. Body chamber with part of the phragmocone, PIMUZ 35927.

Type locality and horizon. Givetian strata near Rich Tamirant, between Oum El Hadej and El Khraouia, Tafilalt, Morocco (see Fig. 1a). The stratigraphic position was determined based on the faunal association of the specimen.

Material. Only the holotype.

Diagnosis. Very large Basiloceras that could reach an adult size of at least $180 \mathrm{~mm}$ in diameter. The aperture was probably reinforced by a thickened peristome, as indicated by distinct grooves parallel to the peristome on the internal mould. The contraction of the body chamber is gradual, almost straight in lateral outline.

Description. The holotype PIMUZ 35927 consists of an internal mould of a nearly complete body chamber and eight partially eroded phragmocone chambers, but without any preserved shell remains. The conch is essentially straight, without a clear indication of curvature in the preserved part of the specimen. The specimen has a length of about $300 \mathrm{~mm}$, a maximum width of $180 \mathrm{~mm}$ and a maximum height of $160 \mathrm{~mm}$, both close to the base of the body chamber. The body chamber itself is $95 \mathrm{~mm}$ long and contracted. A broad hyponomic sinus is present, indicating the ventral side. The aperture is subtriangular with a width of $140 \mathrm{~mm}$ and a height of c. $100 \mathrm{~mm}$, whereas the ventral part of the peristome is not completely traceable due to erosion. The dorsal side of the body chamber is distinctively flattened, while the ventral side is more rounded. The peristome has a rounded dorsal projection that reaches about $30 \mathrm{~mm}$ further anteriorly than the ventral side. Parallel to the dorsal projection is a groove at a distance of about $10 \mathrm{~mm}$ behind the aperture. The septal distance is $9 \mathrm{~mm}$ in the most adoral chamber and up to $15 \mathrm{~mm}$ in the adapical chambers, indicating septal crowding took place in the adult individual close to the cessation of growth.

Discussion. Basiloceras goliath differs from B. david sp. nov. in its much larger adult size. Furthermore, it has a less strongly contracted dorsum at the body chamber.

Remarks. Unfortunately, the position and the shape of the siphuncle are unclear in this species. However, the body chamber is morphologically so similar to Basiloceras david, thus suggesting a close relationship of the two species. Thus, we infer that the siphuncle of B. goliath is probably also located close to the ventral shell wall, a condition that is quite common in oncocerids. B. goliath was chosen as the type species because the body chamber of the holotype is better preserved and a larger portion of the phragmocone is available, thus better displaying the general conch shape.

Basiloceras david sp. nov.

Figures 4a-e, 6

Etymology. After David, the biblical figure, referring to the small size compared to the type species.

Holotype. Body chamber with a small part of the phragmocone, PIMUZ 35928.

Type locality and horizon. Jebel Ouaoufilal (Filon 12), middle Eifelian, Subanarcestes macrocephalus Zone (Fig. 1b).

Material. Only the holotype. 


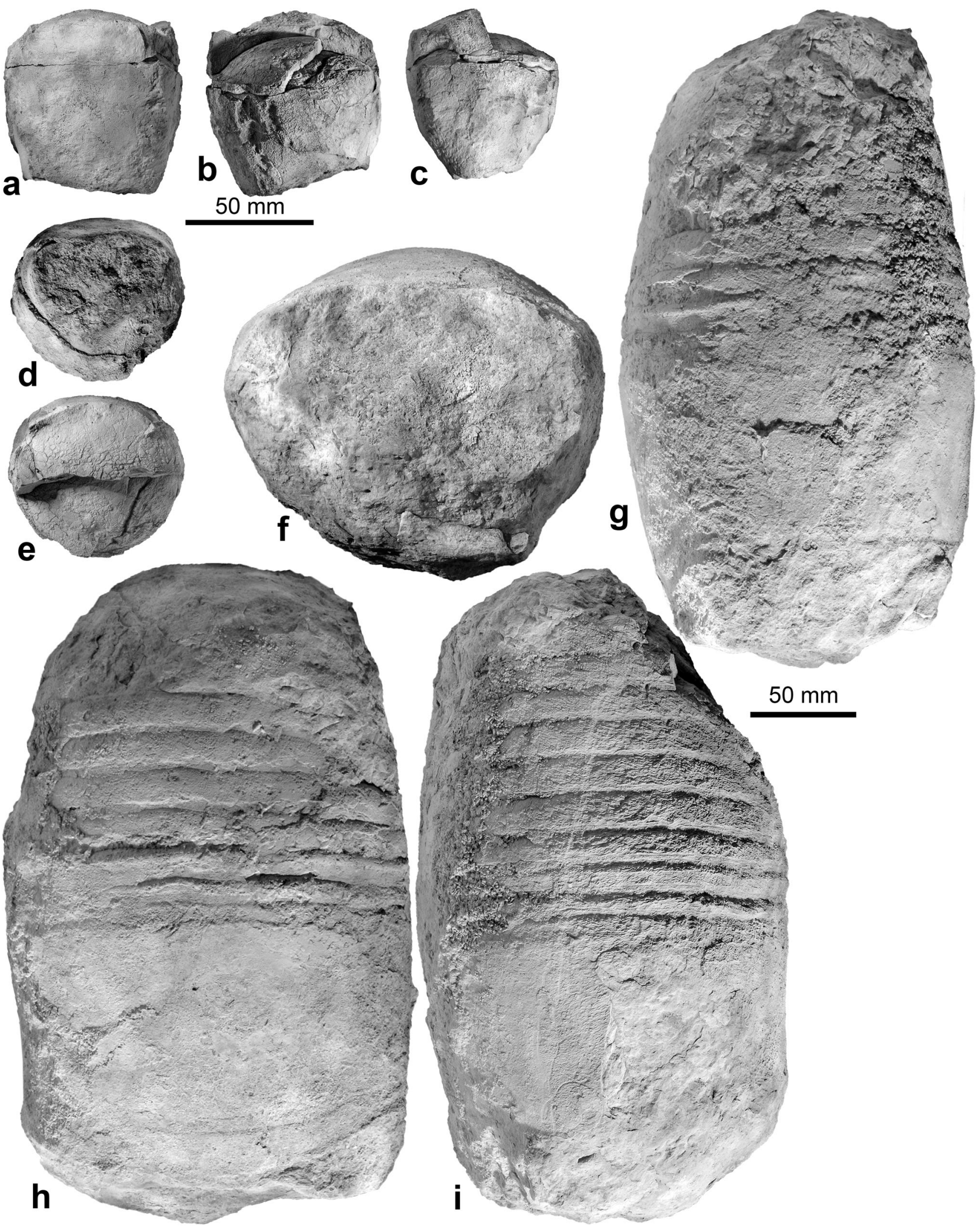

Fig. 4 Basiloceras gen. nov. All specimens were whitened with $\mathrm{NH}_{4} \mathrm{Cl}$. a-e Basiloceras david sp. nov., holotype, PIMUZ 35928, Eifelian, Jebel Ouaoufilal. Dorsal (a), ventral (b), lateral (dorsum left) (c), adoral (d) and adapical (e) view. f, i Basiloceras goliath sp. nov., holotype, PIMUZ 35927, Givetian, SE of Oum El Hadej. Adoral (f), lateral (dorsum left) (g), dorsal (h) and ventral (i) view 


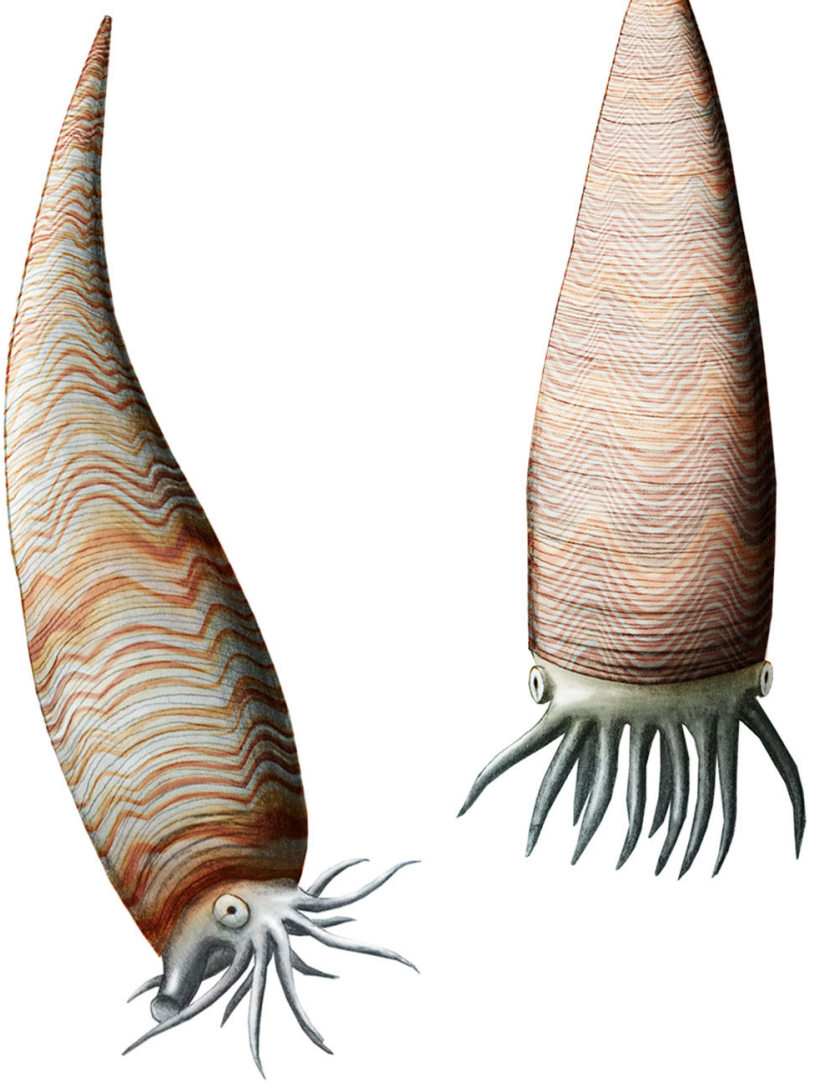

Fig. 5 Possible life reconstructions of Basiloceras goliath sp. nov. in lateral (left) and dorsal (right) view. Possibly, the phragmocone was straight and not slightly curved as shown here

Diagnosis. Basiloceras with a conch width of c. $80 \mathrm{~mm}$ at the base of the adult body chamber.

Description. The holotype PIMUZ 35928 is a body chamber with three partly preserved septa. It has a width of $78 \mathrm{~mm}$ and a height of $72 \mathrm{~mm}$ at the base of the body chamber. The entire specimen has a length of $80 \mathrm{~mm}$, out of which $54 \mathrm{~mm}$ belong to the body chamber. Probably, the most adoral part of the body chamber is missing, but the slight change from a convex to a concave outline near the aperture and the amount of contraction indicate that likely only a small part is missing. The aperture has a rounded subtriangular shape, measuring $59 \mathrm{~mm}$ in width and $42 \mathrm{~mm}$ in height. The broad hyponomic sinus indicates the ventral side. The dorsum is distinctively flattened, while the venter is rounded. Both are convex in lateral outline, converging towards the aperture. The phragmocone chambers have a length of about $4-5 \mathrm{~mm}$. The phragmocone has a width of $73 \mathrm{~mm}$ at the most adapical septum, $13 \mathrm{~mm}$ behind the base of the body chamber. The conch height is not discernible at the same position because the ventral parts of the septa are missing. Since only the most
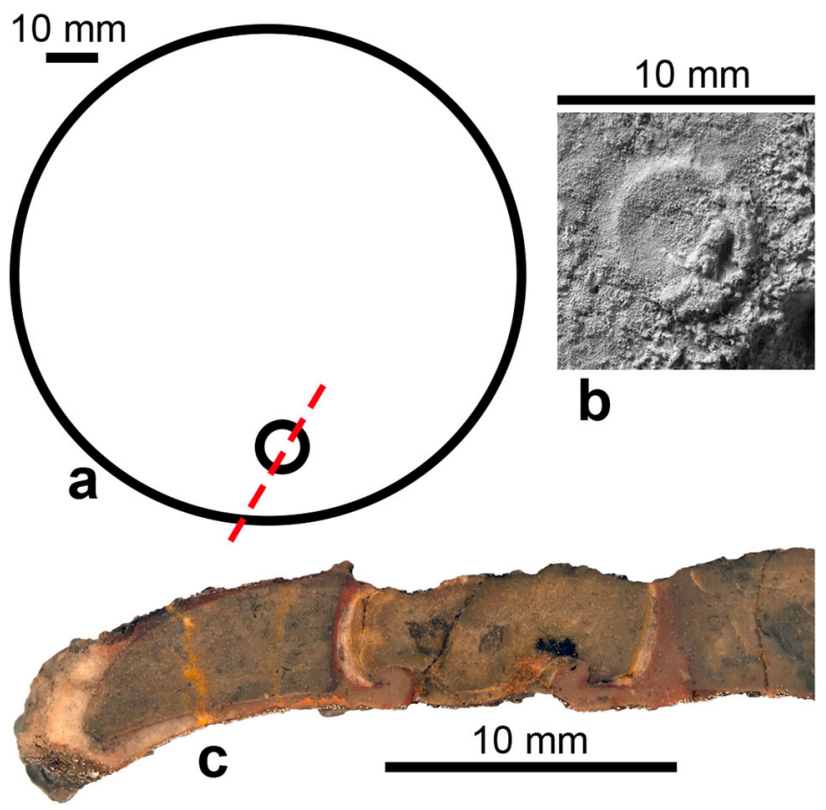

Fig. 6 Details of the siphuncle of Basiloceras david sp. nov., holotype, PIMUZ 35928. a Reconstructed outline of the last septum in adapical view, showing the position of the siphuncle and where the last chamber has been cut. b Detail of the siphuncle at the last septum with the last chamber removed, adapical view (whitened with $\mathrm{NH}_{4} \mathrm{Cl}$ ). c Polished section through the siphuncle (photographed under $\mathrm{H}_{2} \mathrm{O}$ )

adoral chamber preserves a part of the siphuncle, the chamber was removed and obliquely cut as shown in Fig. 6 a to study the structure of the siphuncle. The surface of the last septum - adoral of the removed septum - shows no traces of radial lamellae (Fig. 6b). The siphuncle has a circular cross section and is situated $9 \mathrm{~mm}$ away from the ventral shell wall. The siphuncular segment is broadly expanded with a maximum diameter of $12 \mathrm{~mm}$ and $4 \mathrm{~mm}$ at the septal foramen. The septal necks are cyrtochoanitic. Although the section is oblique to the plane of symmetry of the conch, the dorsal septal neck appears to be slightly closer to the connecting ring, which probably results from a scalariform siphuncle. The connecting ring is thick and consists of two layers: a thin outer layer of brown colour and a white inner layer.

Discussion: In addition to the above described differences to Basiloceras goliath, the holotype of B. david lacks the arched grooves near the aperture of the former. However, this could be due to the incomplete preservation or due to growth irregularities in the holotype of B. goliath.

Remarks. The shape of the body chamber corresponds well to the holotype of $B$. goliath, but the conch is much smaller. Large intraspecific variation of adult size is common in oncocerids and has in some cases been attributed to sexual dimorphism (Stridsberg 1985), but the stratigraphic gap and the very large size difference between $B$. goliath 


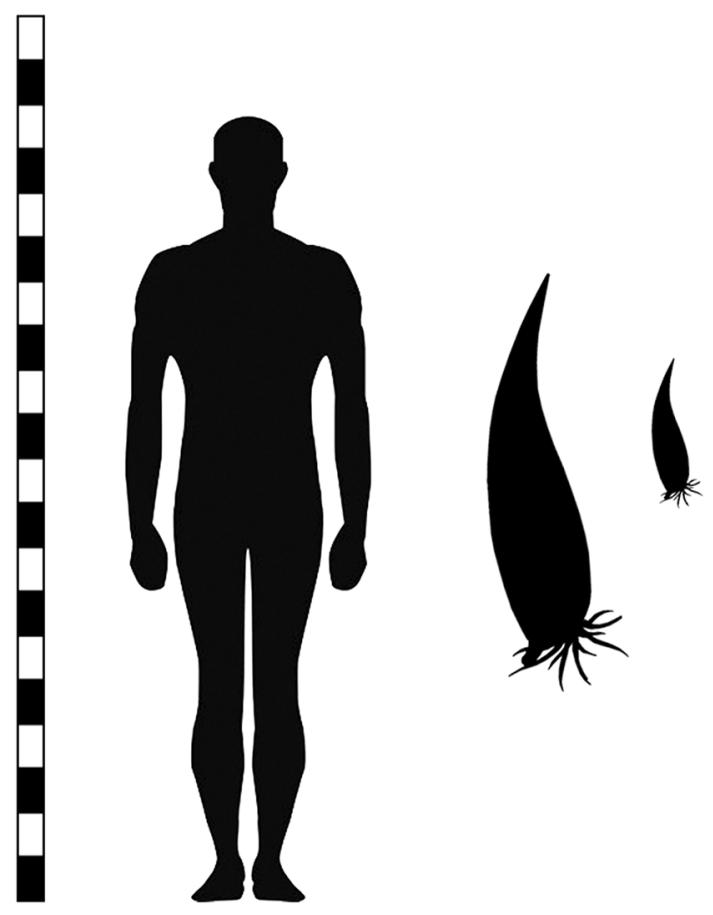

Fig. 7 Size reconstruction of Basiloceras goliath (middle) and $B$. david (right) compared to a human (left). Scale bar $=2 \mathrm{~m}$

and B. david (Fig. 7) speak against the inclusion of both specimens in the same species, although we cannot rule this out with certainty.

Acknowledgements We thank the Swiss National Foundation for financial support (Project Number 200020_132870). We are thankful to the Ministère de l'Energie, des Mines, de l'Eau et de l'Environnement (Direction du Développement Minier, Division du Patrimoine, Rabat, Morocco) for providing working permits. Markus Hebeisen (Zürich, Switzerland) is thanked for advice for the preparation of the holotype of Basiloceras goliath. Said Oukherbouch (Tafraoute, Morocco) collected the large specimen and provided further information about its locality. We are grateful to Adam T. Halamski (Warszawa, Poland) for his help with the identification of the brachiopods and to Olev Vinn (Tartu, Estonia) for comments on the microconchids. Vojtěch Turek (Prague, Czech Republic) is acknowledged for showing us Barrande's collection. We thank the reviewers David Evans (Peterborough, England), Štepan Manda (Prague, Czech Republic) and Björn Kröger (Helsinki, Finland), whose comments helped to improve the manuscript. Daniel Marty (Basel, Switzerland) is thanked for his editorial work.

\section{References}

Afhüppe, L., Becker, R. T., \& Hartenfels, S. (2018). New data on cyrto- and gyroconic nautiloids from the Devonian of the eastern Anti-Atlas. Münstersche Forschungen zur Geologie und Paläontologie, 110, 15-16.

Baird, G. C., Brett, C. E., \& Frey, R. C. (1989). "Hitchhiking" epizoans on orthoconic cephalopods: preliminary review of the evidence and its implications. Senckenbergiana Lethaea, 69, 439-465.
Barrande, J. (1865-1877). Système Silurien du centre de la Bohême, 1ère Partie: Recherches Paléontologiques, Volume II, Classe de Mollusques, Ordre des Céphalopodes.-1ère Série, pls. 1-107 (1865); 2me Série, pls. 108-244 (1866); 3me Série, pls. 245-350 (1868); 4me Série, pls. 351-460 (1870); Supplément et Série tardive, pls. 461-544 (1877); Texte I, 712 pp. (1867); Texte II, 266 pp. (1870); Texte III, 804 pp. (1874); Texte IV, 742 pp. (1877); Texte V, 743 pp. (1877); Supplément et Série tardive, Texte, 297 pp. (1877). Prague \& Paris: Published privately.

Becker, R. T., El Hassani, A., Aboussalam, Z. S., Hartenfels, S., \& Baidder, L. (2018). The Devonian and Lower Carboniferous of the eastern Anti-Atlas: introduction to a "cephalopod paradise". Münstersche Forschungen zur Geologie und Paläontologie, 110, $145-157$.

Brazeau, M. D., \& Friedman, M. (2015). The origin and early phylogenetic history of jawed vertebrates. Nature, 420, 490-497.

Brett, C. E., \& Walker, S. E. (2002). Predators and predation in Paleozoic marine environments. Paleontological Society Papers, 8, 93-118.

Chlupáč, I. (1983). Stratigraphical position of Barrande's paleontological localities in the Devonian of Central Bohemia. $\check{C}$ asopis pro Mineralalogii a Geologii, 28, 261-275.

Chlupáč, I., Lukeš, P., \& Zikmundová, J. (1979). The Lower/Middle Devonian boundary beds in the Barrandian area, Czechoslovakia. Geologica et Palaeontologica, 13, 125-156.

Clarke, M. R., Denton, E. J., \& Gilpin-Brown, J. B. (1979). On the use of ammonium for buoyancy in squids. Journal of the Marine Biological Association of the United Kingdom, 59, 259-276.

Collins, D. H. (1969). Devonian nautiloids from northern Canada. Geological Survey of Canada Bulletin, 182, 31-75.

Crick, R. E. (1988). Buoyancy regulation and macroevolution in nautiloid cephalopods. Senckenbergiana Lethaea, 69(1), 13-42.

Crick, R. E., \& Teichert, C. (1979). Siphuncular structures in the Devonian nautiloid Archiacoceras from the Eifel of West Germany. Palaeontology, 22, 747-766.

Dahl, T. W., Hammarlund, E. U., Anbar, A. D., Bond, D. P. G., Gill, B. C., Gordon, G. W., et al. (2011). Devonian rise in atmospheric oxygen correlated to the radiations of terrestrial plants and large predatory fish. PNAS, 107, 17911-17915.

Davis, R. A., Mapes, R. H., \& Klofak, S. (1999). Epizoa on externally shelled cephalopods. In A. Y. Rozanov \& A. A. Shevyrev (Eds.), Fossil cephalopods: Recent advances in their study (pp. 32-51). Moscow: Russian Academy of Sciences, Paleontological Institute.

De Baets, K., Klug, C., \& Plusquellec, Y. (2010). Zlíchovian faunas with early ammonoids from morocco and their use for the correlation of the eastern Anti-Atlas and the western Dra Valley. Bulletin of Geosciences, 85(2), 317-352.

De Baets, K., \& Munnecke, A. (2018). Evidence for Palaeozoic orthoconic cephalopods with bimineralic shells. Palaeontology, 61(2), 173-181.

Denton, E. J., \& Gilpin-Brown, J. B. (1966). On the buoyancy of the pearly nautilus. Journal of the Marine Biological Association of the United Kingdom, 46(03), 723.

Dzik, J. (1984). Phylogeny of the Nautiloidea. Palaeontologia Polonica, 45, 1-320.

Flower, R. H. (1938). Devonian brevicones of New York and adjacent areas. Palaeontographica Americana, 2(9), 1-84.

Flower, R. H. (1943). Investigations of actinosiphonate cephalopods. Bulletin of American Paleontology, 28(109), 30-67.

Flower, R. H. (1957). Nautiloids of the Paleozoic. In H. Ladd (Ed.), Treatise of marine ecology and paleoecology (Vol. 67, pp. 829-852). Memoir: Geological Society of America. (2).

Flower, R. H. (1964). Nautiloid shell morphology. New Mexico Institute of Mining and Technology Memoir, 12, 79. 
Flower, R. H., \& Kummel, B. (1950). A classification of the Nautiloidea. Journal of Paleontology, 24(5), 604-616.

Foerste, A. F. (1926). Actinosiphonate, Trochoceroid and other cephalopods. Denison University Bulletin, Journal of the Scientific Laboratories, 21, 285-383.

Frey, R. C. (1989). Paleoecology of a well-preserved nautiloid assemblage from a Late Ordovician shale unit, Southwestern Ohio. Journal of Paleontology, 63(5), 604-620.

Frey, R. C. (1995). Middle and Upper Ordovician nautiloid cephalopods of the Cincinnati Arch Region of Kentucky, Indiana, and Ohio. Contributions to the Ordovician paleontology of Kentucky and nearby states: U.S. Geological Survey Professional Paper, 1066P, P1-P126.

Frey, L., Naglik, S., Hofmann, S., Schemm-Gregory, S., Frýda, J., Kröger, B., et al. (2014). Diversity and palaeoecology of Early Devonian invertebrate associations in the Tafilalt (Anti-Atlas, Morocco). Bulletin of Geosciences, 89(1), 75-112.

Frye, M. W. (1987). Upper Ordovician (Harjuan) oncoceratid nautiloids from the Boda Limestone, Siljan District. Sweden. Geologiska Föreningen i Stockholm Förhandlingar, 109(1), 83-99.

Furnish, W. M., \& Glenister, B. F. (1964). Paleoecology. In R. C. Moore (Ed.), Treatise on invertebrate paleontology, Part K, Mollusca 3, Cephalopoda (pp. K114-K124). Lawrence: Geological Society of America and University of Kansas Press.

Gabbott, S. E. (1999). Orthoconic cephalopods and associated fauna from the Late Ordovician Soom Shale Lagerstatte, South Africa. Palaeontology, 42(1), 123-148.

Gnoli, M., \& Serventi, P. (2009). Silurian nautiloid cephalopods from Sardinia: the state of the art. Rendiconti della Società Paleontologica Italiana, 3(1), 109-118.

Halamski, A. T., \& Baliński, A. (2013). Middle Devonian brachiopods from the southern Maïder (eastern Anti-Atlas, Morocco). Annales Societatis Geologorum Poloniae, 83, 243-307.

Hautmann, H., Ware, D., \& Bucher, H. (2017). Geologically oldest oysters were epizoans on Early Triassic ammonoids. Journal of Molluscan Studies, 83, 253-260.

Hölder, H. (1990). Über die Muschelgattung Placunopsis (Pectinacea, Placunopsidae) in Trias und Jura. Stuttgarter Beiträge zur Naturkunde. Serie B (Geologie und Paläontologie), 165, 1-63.

Holland, C. H. (2007). Cyrtoconic nautiloid cephalopods from the British Silurian. Proceedings of the Geologists' Association, 118(4), 365-373.

Iba, Y., Sano, S.-I., \& Goto, M. (2015). Large belemnites were already common in the Early Jurassic-new evidence from Central Japan. Paleontological Research, 19(1), 21-25.

Klug, C. (2007). Sublethal injuries in Early Devonian cephalopod shells from Morocco. Acta Palaeontologica Polonica, 52(52), 749-759.

Klug, C., De Baets, K., Kröger, B., Bell, M. A., Korn, D., \& Payne, J. L. (2015). Normal giants? Temporal and latitudinal shifts of Palaeozoic marine invertebrate gigantism and global change. Lethaia, 48(2), 267-288.

Klug, C., Frey, L., Pohle, A., de Baets, K., \& Korn, D. (2017). Palaeozoic evolution of animal mouthparts. Bulletin of Geosciences, 92(4), 511-524.

Klug, C., \& Korn, D. (2001). Epizoa and post-mortem epicoles on cephalopod shells-Devonian and Carboniferous examples from Morocco. Berliner geowissenschaftliche Abhandlungen, 36, $145-155$

Klug, C., Korn, D., Richter, U., \& Urlichs, M. (2004). The black layer in cephalopods from the German Muschelkalk (Middle Triassic). Palaeontology, 47, 1407-1425.
Klug, C., Kröger, B., Kiessling, W., Mullins, G. L., Servais, T., Frýda, J., et al. (2010). The Devonian nekton revolution. Lethaia, 43(4), $465-477$.

Klug, C., Kröger, B., Korn, D., Martin, R., Schemm-Gregory, M., De Baets, K., et al. (2008). Ecological change during the early Emsian (Devonian) in the Tafilalt (Morocco), the origin of the Ammonoidea, and the first African pyrgocystid edrioasteroids, machaerids and phyllocarids. Palaeontographica Abteilung A, 283(4-6), 83-176.

Klug, C., \& Lehmkuhl, A. (2004). Soft-tissue attachment and taphonomy of the Middle Triassic nautiloid Germanonautilus. Acta Palaeontologica Polonica, 49, 243-258.

Klug, C., \& Pohle, A. (2018). The eastern Amessoui Syncline-a hotspot for Silurian to Carboniferous cephalopod research. Münstersche Forschungen zur Geologie und Paläontologie, $110,244-260$.

Kröger, B. (2003). The size of the siphuncle in cephalopod evolution. Senckenbergiana Lethaea, 83, 39-52.

Kröger, B. (2008). Nautiloids before and during the origin of ammonoids in a Siluro-Devonian section in the Tafilalt, AntiAtlas, Morocco. Special Papers in Palaeontology, 79, 1-110.

Kröger, B., \& Aubrechtová, M. (2018). Cephalopods from reef limestone of the Vasalemma Formation, northern Estonia (latest Sandbian, Upper Ordovician) and the establishment of a local warm-water fauna. Journal of Systematic Palaeontology, 16(10), 799-839.

Kröger, B., Klug, C., \& Mapes, R. H. (2005). Soft-tissue attachments in orthocerid and bactritid cephalopods from the Early and Middle Devonian of Germany and Morocco. Acta Palaeontologica Polonica, 50(2), 329-342.

Kröger, B., Servais, T., \& Zhang, Y. (2009). The origin and initial rise of pelagic cephalopods in the Ordovician. PLoS One, 4(9), e7262.

Kubodera, T., \& Mori, K. (2005). First-ever observations of a live giant squid in the wild. Proceedings of the Royal Society B: Biological Sciences, 272(1581), 2583-2586.

Landman, N. H., Saunders, W. B., Winston, J. E., \& Harries, P. J. (2010). Incidence and kinds of epizoans on the shells of live Nautilus. In W. B. Saunders \& N. H. Landman (Eds.), Nautilusthe biology and palaeobiology of a living fossil (pp. 163-177). Dordrecht: Springer.

Landois, H. (1895). Die Riesenammoniten von Seppenrade, Pachydiscus Zittel seppenradensis H. Landois. Jahresbericht der Zoologischen Sektion des Westfälischen Provinzial- Vereins für Wissenschaft und Kunst, 23, 99-108.

Lemanis, R., Zachow, S., Fusseis, F., \& Hoffmann, R. (2014). A new approach using high-resolution computed tomography to test the buoyant properties of chambered cephalopod shells. Paleobiology, 41, 313-329.

Manda, Š. (2008). Palaeoecology and palaeogeographic relations of the Silurian phragmoceratids (Nautiloidea, Cephalopoda) of the Prague Basin (Bohemia). Bulletin of Geosciences, 83(1), 39-62.

Manda, Š., \& Frýda, J. (2010). Silurian-Devonian boundary events and their influence on cephalopod evolution: Evolutionary significance of cephalopod egg size during mass extinctions. Bulletin of Geosciences, 85(3), 513-540.

Manda, Š., \& Turek, V. (2011). Late Emsian Rutoceratoidea (Nautiloidea) from the Prague Basin, Czech Republic: Morphology, diversity and palaeoecology. Palaeontology, 54(5), 999-1024.

Manger, W. L., Meeks, L. K., \& Stephen, D. A. (1999). Pathologic gigantism in Middle Carboniferous cephalopods, southern midcontinent, United States. In F. Olóriz \& F. J. Rodríguez-Tovar (Eds.), Advancing research on living and fossil cephalopods (pp. 77-89). Boston: Springer. 
Mutvei, H. (2011). Silurian oncocerid Octamerella (Cephalopoda) from Gotland, Sweden. Gff, 133(3-4), 125-133.

Mutvei, H. (2013). Characterization of nautiloid orders Ellesmerocerida, Oncocerida, Tarphycerida, Discosorida and Ascocerida: New superorder Multiceratoidea. Gff, 135(2), 171-183.

Naglik, C., Rikhtegar, F., \& Klug, C. (2016). Buoyancy of some Palaeozoic ammonoids and their hydrostatic properties based on empirical 3D-models. Lethaia, 49(1), 3-12.

Niko, S., \& Nishida, T. (2003). Devonohelicoceras hidaense, a new torticonic oncocerid (Cephalopoda) from the Lower Devonian of Central Japan. In Proceedings of the Japan Academy, Series B.

Pohle, A., \& Klug, C. (2018a). Body size of orthoconic cephalopods from the late Silurian and Devonian of the Anti-Atlas (Morocco). Lethaia, 51(1), 126-148.

Pohle, A., \& Klug, C. (2018b). Early and Middle Devonian Cephalopods from Hamar Laghdad (Tafilalt, Morocco) and remarks on epicoles and cameral deposits. Neues Jahrbuch für Geologie und Paläontologie Abhandlungen, 290(1-3), 203-240.

Pruss, S. B., Payne, J. L., \& Bottjer, D. J. (2007). Placunopsis bioherms: The first metazoan buildups following the endPermian mass extinction. Palaios, 22, 17-23.

Rakociński, M. (2011). Sclerobionts on upper Famennian cephalopods from the Holy Cross Mountains, Poland. Palaeobiodiversity and Palaeoenvironments, 91, 63-73.

Rosa, R., Lopes, V. M., Guerreiro, M., Bolstad, K., \& Xavier, J. C. (2017). Biology and ecology of the world's largest invertebrate, the colossal squid (Mesonychoteuthis hamiltoni): A short review. Polar Biology, 40(9), 1871-1883.

Seilacher, A. (1982). Ammonite shells as habitats in the Posidonia Shale_floats or benthic islands? Neues Jahrbuch für Geologie und Paläontologie Monatshefte, 1982, 98-114.

Shimansky, V. N. (1957). Carboniferous Oncoceratida. Doklady Akademii Nauk SSSR, 112(3), 530-532. (in Russian).

Shimansky, V. N. (1968). Carboniferous Orthoceratida, Oncoceratida, Actinoceratida and Bactritida. Akademiya Nauk SSSR, Trudy Paleontologicheskogo Instituta, 117, 1-148. (in Russian).

Stevens, G. R. (1988). Giant ammonites: A review. In J. Wiedemann \& J. Kullmann (Eds.), Cephalopods present and past-O. H. Schindewolf-Symposium Tübingen 1985 (2nd International Cephalopod Symposium) (pp. 141-166). Stuttgart: Schweizerbart'sche Verlagsbuchhandlung.

Stridsberg, S. (1985). Silurian oncocerid cephalopods from Gotland. Fossils and Strata, 18, 1-65.

Stridsberg, S. (1990a). Orientation of cephalopod shells in illustrations. Palaeontology, 33(1), 243-248.

Stridsberg, S. (1990b). Internal shell destruction in some Silurian nautiloids. Paläontologische Zeitschrift, 64(3), 213-220.

Sweet, W. C. (1959). Muscle-attachment impressions in some Paleozoic nautiloid cephalopods. Journal of Paleontology, 33(2), 293-304.

Sweet, W. C. (1964). Nautiloidea-Oncocerida. In R. C. Moore (Ed.), Treatise on invertebrate paleontology, Part K, Mollusca 3, Cephalopoda (pp. K277-K320). Lawrence: Geological Society of America and University of Kansas Press.

Tajika, A., Naglik, C., Morimoto, N., Pascual-Cebrian, E., Hennhöfer, D. K., \& Klug, C. (2015). Empirical 3D-model of the conch of the Middle Jurassic ammonite microconch Normannites, its buoyancy, the physical effects of its mature modifications and speculations on their function. Historical Biology, 27, 181-191.

Taylor, P. D., \& Vinn, O. (2006). Convergent morphology in small spiral worm tubes ('Spirorbis') and its palaeoenvironmental implications. Journal of the Geological Society, London, 163, 225-228.
Teichert, C. (1964). Morphology of Hard Parts. In R. C. Moore (Ed.), Treatise on invertebrate paleontology, Part K, Mollusca 3, Cephalopoda (pp. K13-K54). Lawrence: Geological Society of America and University of Kansas Press.

Teichert, C. (1967). Major features of cephalopod evolution. In C. Teichert \& E. L. Yochelson (Eds.), Essays in paleontology and stratigraphy: R.C. Moore commemorative volume (pp. 162-210). Lawrence: University of Kansas Press.

Teichert, C., \& Kummel, B. (1960). Size of endoceroid cephalopods. Breviora, Museum of Comparative Zoology, 128, 1-7.

Termier, G., \& Termier, H. (1950). Paléontologie marocaine, II: invertébrés de l'ère primaire. Fascicule III, Mollusques. Notes et Mémoires du Service Carte Géologique du Maroc, 78, 1-246.

Todd, J.A., \& Hagdorn, H. (1993). First record of Muschelkalk Bryozoa: The earliest ctenostome body fossils. In H. Hagdorn, and A. Seilacher (Eds.) Muschelkalk. Schöntaler Symposium 1991. Sonderbände der Gesellschaft für Naturkunde in Württemberg, 2, 285, 286. Goldschneck, Stuttgart - Korb.

Vinn, O. (2006). Two new microconchid (Tentaculita BOUCEK, 1964) genera from the Early Palaeozoic of Baltoscandia and England. Neues Jahrbuch für Geologie und Paläontologie Monatshefte, 2006(2), 89-100.

Wani, R. (2007). How to recognize in situ fossil cephalopods: Evidence from experiments with modern Nautilus. Lethaia, 40, 305-311.

Ward, P. (1986). Rates and processes of compensatory buoyancy change in Nautilus macromphalus. The Veliger, 28(4), 356-368.

Watkins, R. (1981). Epizoan ecology in the type Ludlow series (Upper Silurian). England. Journal of Paleontology, 55(1), 29-32.

Weedon, M. J. (1991). Microstructure and affinity of the enigmatic Devonian tubular fossil Trypanopora. Lethaia, 24(2), 227-234.

Westermann, G. E. G. (1973). Strength of concave septa and depth limits of fossil cephalopods. Lethaia, 6(4), 383-403.

Westermann, G. E. G. (1975). Architecture and buoyancy of simple cephalopod phragmocones and remarks on ammonites. Paläontologische Zeitschrift, 49(3), 221-234.

Westermann, G. E. G. (1985). Post-mortem descent with septal implosion in Silurian nautiloids. Paläontologische Zeitschrift, 59(1), 79-97.

Wyse Jackson, P. N., \& Key, M. M., Jr. (2014). Epizoic bryozoans on cephalopods through the Phanerozoic: A review. Studi Trentini di Scienze Naturali, 94, 283-291.

Zatoń, M., \& Krawczyński, W. (2011). New Devonian microconchids (Tentaculita) from the Holy Cross Mountains. Poland. Journal of Paleontology, 85(4), 757-769.

Zatoń, M., \& Olempska, E. (2017). A family-level classification of the Order Microconchida (Class Tentaculita) and the description of two new microconchid genera. Historical Biology, 29(7), 885-894.

Zhuravleva, F. A. (1962). Order Oncoceratida. In W. E. Ruzhencev (Ed.), Osnovy paleontologii. Mollyuski-golovonogie (pp. 101-115). Moscow: Izdatelstvo Akademiya Nauk SSSR. (in Russian).

Zhuravleva, F. A. (1972). Devonian nautiloids. Order Discosorida. Trudy Paleontologicheskogo Instituta Academiya Nauk SSSR, 134, 1-320. (in Russian).

Zhuravleva, F. A. (1974). Devonian nautiloids. Orders Oncoceratida, Tarphyceratida, Nautilida. Trudy Paleontologicheskogo Instituta Academiya Nauk SSSR, 142, 1-159. (in Russian). 